\title{
Acute haemorrhagic oedema of infancy: a benign cause of a formidable rash
}

\author{
Ilsa Louisa Haeusler, ${ }^{1,2}$ Ranjini Mohan²
}

${ }^{1}$ Institute of Child Health, University College London, London, UK

${ }^{2}$ Department of Paediatrics, Oxford University Hospitals NHS Foundation Trust, Oxford, UK

\section{Correspondence to} Dr llsa Louisa Haeusler, ilsa.haeusler@gmail.com

Accepted 10 December 2017

\section{(1) \\ CrossMark}

To cite: Haeusler IL, Mohan R. BMJ Case Rep Published Online First: [please include Day Month Year]. doi:10.1136/bcr-2017223368

\section{DESCRIPTION}

A 17-month-old girl presented with a 3-day history of cough, coryzal symptoms and low-grade fevers, and a 2-day history of rash and swelling. The rash began as a circular purpuric lesion over the posterior right wrist. New lesions rapidly appeared on her limbs (particularly her forearms), right cheek, right ear, and buttocks (figure 1). Her trunk and mucous membranes were spared. There was non-pitting oedema underlying the rash. She had no joint swelling nor abdominal tenderness. She was unsettled but systemically well.

Meningococcal septicaemia was initially suspected and she was treated with a bolus of intravenous fluid and ceftriaxone. Haematology, biochemistry, and clotting studies were subsequently normal and antibiotics were stopped.

Over the following 3 days, she remained systemically well but developed new lesions on her arms and the oedema worsened. The lesions became so large that most of her hands and forearms were covered with purpura as the lesions coalesced. Older lesions began to fade into a darker brown colour (figure 2).

Finkelstein's disease, or acute haemorrhagic oedema of infancy (AHOI), was diagnosed. The rash and oedema completely resolved, without complication, over 3 weeks.

AHOI is a rare small vessel vasculitis with an unknown incidence. The median age of onset is 11 months, with $80 \%$ of cases occurring between 6 and 24 months. In $66 \%$ of cases, a proceeding prodromal illness is described, most often a respiratory or urinary tract infection or diarrhoea. ${ }^{12}$ Although there is a spectrum of appearances the lesions are typically annular and purpuric, often with a target-like appearance, associated with

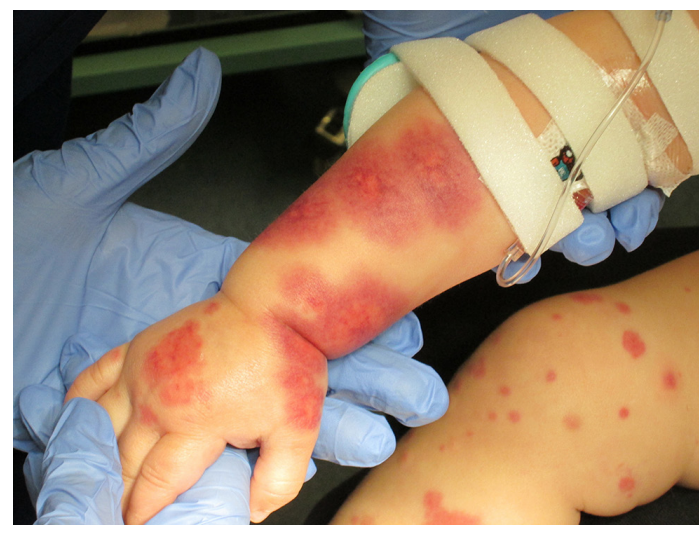

Figure 1 Early rash on hand and forearm with underlying oedema.

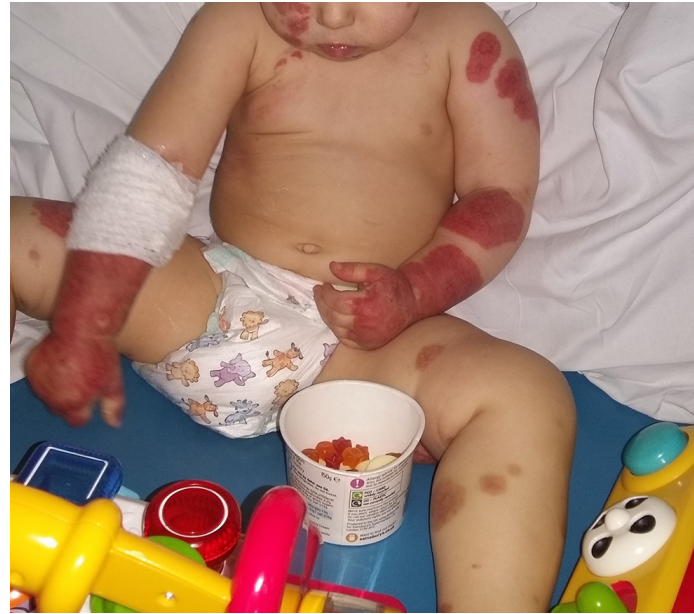

Figure 2 Coalesced rash on arms with fading lesions on the legs.

underlying non-pitting oedema. The individual lesions increase in size and tend to coalesce as the disease progresses. AHOI most commonly affects the face, ears, and limbs (lower more frequently than upper).

Complications such as glomerulonephritis and joint swelling are reported in fewer than $10 \%$ of cases. ${ }^{1}$ There are no known clinical indicators to predict who will develop complications, although such patients tend to be older (median age of 19 months). AHOI is most frequently misdiagnosed as meningococcal septicaemia, but antibiotics are unnecessary if there is no other suspicion of sepsis. $^{1}$

Management is symptomatic and steroids are not indicated. Resolution takes a median of 10 days. ${ }^{1}$ Recurrences and complications are very rare. Parents can be reassured that the rash and oedema will resolve without treatment.

\section{Learning points}

- Acute haemorrhagic oedema of infancy is a benign vasculitis characterised by purpura and oedema.

- In the majority of cases, a preceding infectious illness is identified.

- No specific treatment is required and resolution takes a median of 10 days.

Twitter@dr_haeusler

Contributors ILH was responsible for drafting the manuscript, and RM undertook the final editing. RM and ILH were both involved with the clinical management of the patient. 
Competing interests None declared.

Patient consent Parental/guardian consent obtained.

Provenance and peer review Not commissioned; externally peer reviewed.

(c) BMJ Publishing Group Ltd (unless otherwise stated in the text of the article) 2018. All rights reserved. No commercial use is permitted unless otherwise expressly granted.

\section{REFERENCES}

1 Fiore E, Rizzi M, Ragazzi M, et al. Acute hemorrhagic edema of young children (cockade purpura and edema): a case series and systematic review. J Am Acad Dermatol 2008;59:684-95.

2 Parker L, Shahar-Nissan K, Ashkenazi-Hoffnung L, et al. Acute hemorrhagic edema of infancy: the experience of a large tertiary pediatric center in Israel. World I Pediatr 2017:1-5.

Copyright 2017 BMJ Publishing Group. All rights reserved. For permission to reuse any of this content visit http://group.bmj.com/group/rights-licensing/permissions.

BMJ Case Report Fellows may re-use this article for personal use and teaching without any further permission.

Become a Fellow of BMJ Case Reports today and you can:

- Submit as many cases as you like

- Enjoy fast sympathetic peer review and rapid publication of accepted articles

- Access all the published articles

Re-use any of the published material for personal use and teaching without further permission

For information on Institutional Fellowships contact consortiasales@bmjgroup.com

Visit casereports.bmj.com for more articles like this and to become a Fellow 